\title{
MULTIPLEX-PCR TO DETECT PATHOGENS AND ANALYSIS OF RELATION OF AGE AND STAGE OF LACTATION OF COWS TO SUB-CLINICAL MASTITIS
}

\author{
Gaddi $\mathrm{RM}^{1}$, Isloor $\mathrm{S}^{1,{ }^{*}}$, Rathnamma $\mathrm{D}^{1}$, Avinash $\mathrm{B}^{4}$, Veeregowda $\mathrm{BM}^{1}$, Bhaskar $\mathrm{R}^{3}$ and Suguna Rao ${ }^{2}$ \\ ${ }^{1}$ Department of Microbiology, Veterinary College, KVAFSU, Hebbal, Bengaluru \\ ${ }^{2}$ Department of Pathology, Veterinary College, KVAFSU, Hebbal, Bengaluru \\ ${ }^{3}$ Instructional Livestock Farm Complex, Veterinary College, KVAFSU, Hebbal, Bengaluru \\ ${ }^{4}$ Acquity Labs Pvt Ltd, HBR Layout, Bengaluru
}

Received - August 05, 2016; Revision - October 10, 2016; Accepted - October 25, 2016

Available Online - October 30, 2016

DOI: http://dx.doi.org/10.18006/2016.4(Spl-3-ADPCIAD).S59.S68

\section{KEYWORDS}

Sub-clinical mastitis

Somatic cell count

Multiplex-PCR

Predominant bacteria

Age groups

Stage of lactation

* Corresponding author

E-mail: kisloor@gmail.com (Shrikrishna Isloor)

Peer review under responsibility of Journal of Experimental Biology and Agricultural Sciences.

Production and Hosting by Horizon Publisher India [HPI] (http://www.horizonpublisherindia.in/).

All rights reserved.

\section{ABSTRACT}

In this study, 225 milk samples were collected sequentially during $1^{\text {st }}$ to $88^{\text {th }}$ day from $25 \mathrm{HF}$ cross cows in an organized farm. First five collections were obtained at a weekly interval (1,7,14,21 and 28 days) and later, fortnightly for two months $(43,58,73$ and 88 days). These milk samples were screened for Subclinical mastitis (SCM) by Somatic Cell Count (SCC). Further, multiplex-PCR for detection of S.aureus, E.coli, S.agalactiae, S.dysgalactiae and S.uberis was employed to detect the major bacterial pathogens. The SCM positivity was assessed based on criteria of SCC $\geq 500,000$ cells $/ \mathrm{ml}$. The study revealed the high prevalence of variable SCM pattern in milking cows by SCC $(73.33 \%)$ in sequentially collected milk samples over a period of 88 days. No specific pattern of prevalence of SCM was observed during the study period. The prevalence of SCM was not influenced by the stage of lactation. In all the stages of lactation and age groups $S$. aureus, Streptococci and E.coli were detected with the predominance of $S$. aureus. The varied distribution of organisms in different stages of lactation did not influence the prevalence of SCM. Further, the high prevalence of SCM was noticed in aged cows. Among these, maximum number of milk samples $(46 \%, 52 / 113)$ revealing the presence of pathogens were obtained from cows in the age group 7-11 years. The multiplex PCR was found an easy and rapid method to detect the predominant pathogens causing SCM. The findings emphasize the need to control SCM through sequential monitoring of SCM through SCC, multiplex-PCR and proper managemental practices.
All the article published by Journal of Experimental Biology and Agricultural Sciences is licensed under a Creative Commons Attribution-NonCommercial 4.0 International License Based on a work at www.jebas.org.

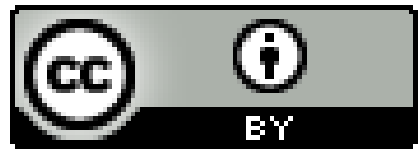




\section{Introduction}

The tremendous growth of dairy industry is crippled by bovine mastitis, the most frequent and costly status as it affects the dairy herd worldwide (Halasa et al., 2007). Mastitis is the inflammation of udder parenchyma characterized by pathological changes in the mammary gland as well as physical and chemical changes of the milk. The disease continues to pose a major threat to the animal husbandry and dairy sector. Despite research for several decades, this condition still poses challenge to the researchers. The overall national economic loss in India due to mastitis was to the tune of Rs 7165.51 crores (Bansal \& Gupta, 2009). It is a multifactorial disease involving three main elements viz cow, the environment and the pathogen and their complex interaction is incompletely understood (Brand et al., 1996).

Broadly bovine mastitis is of two types, viz. clinical, where the appearance of udder and milk changes and subclinical, wherein the appearance of udder as well as milk is normal. Therefore detection of clinical cases of mastitis (CM) is easy than subclinical form (SCM), which needs application of laboratory tests. The major pathogens responsible for Bovine Mastitis can be further classified as Contagious (Staphylococcus aureus, $S$. agalactiae) and environmental (Escherichia coli, $S$. dysgalactiae and S. uberis). Initially, clinical cases could begin as subclinical and hence controlling SCM is the best way to reduce the clinical cases indirectly (Harmon, 1994).

An early diagnosis of mastitis is utmost important to avoid fibrosis of the udder and milk loss. Conventionally, Electrical conductivity (EC), California Mastitis Test (CMT), Somatic Cell Count (SCC) is although rapid ambiguous. The conventional bacterial culturing is cumbersome, time consuming and ambiguous (Hegde, 2011; Nithinprabhu et al., 2013). Of late, the DNA based molecular tools, especially multiplex PCR has been developed and found specific and rapid in detection of major mastitis causing pathogens (Hegde, 2011; Shome et al., 2011).

Bovine mastitis is highly complex disease influenced by various factors, such factors could be analyzed by prospective cohort study based on the sequentially collected data and determines the risk factors. Considering the aforementioned facts, the present study was designed with a focus on Multiplex PCR for detection of predominant pathogens at various time points within a single farm and analyzing the influence of age of cow and stage of lactation with relation to SCM detected by SCC.

\section{Materials and methods}

\subsection{Sampling details}

A temporal study was carried out to sequentially monitor the sub-clinical cases of bovine mastitis due to major bacterial pathogens such as S.aureus, E.coli, S.agalactiae, S.dysgalactiae and S.uberis. In this approach, conventional SCC and Multiplex-Polymerase Chain Reaction (M-PCR) were employed to sequentially monitor the SCM. Furthermore, the effect of stage of lactation and age group of milking cows on prevalence of SCM and in turn influence of SCM on milk production was also investigated. In view of this, the milk samples were sequentially collected from $1^{\text {st }}$ to $88^{\text {th }}$ day. First five collections were collected at a weekly interval $\left(1^{\text {st }}, 7^{\text {th }}\right.$ $, 14^{\text {th }}, 21^{\text {st }}$ and $28^{\text {th }}$ days) and later, fortnightly for two months $\left(43^{\text {rd }}, 58^{\text {th }}, 73^{\text {rd }}\right.$ and $88^{\text {th }}$ days $)$.

Table 1 Prevalence of SCM in dairy cows by SCC, at different age and stage of lactation.

\begin{tabular}{|lccccccc|} 
Days & $\begin{array}{c}\text { No. pos/No. } \\
\text { tested, percent }\end{array}$ & \multicolumn{2}{c}{$\begin{array}{c}\text { Age Groups (years) } \\
\text { No. pos/No. tested, percent }\end{array}$} & \multicolumn{2}{c|}{$\begin{array}{c}\text { Stage of Lactation } \\
\text { No. pos/No. tested, percent }\end{array}$} \\
\cline { 2 - 9 } & $\left(1-88^{\text {th }}\right.$ Day) & $3-5$ & $5-7$ & $7-11$ & Early & Mid & Late \\
\hline $\mathbf{1}$ & $25 / 25,100$ & $7 / 7,100$ & $7 / 7,100$ & $11 / 11,100$ & $15 / 15,100$ & $5 / 5,100$ & $5 / 5,100$ \\
\hline $\mathbf{7}$ & $19 / 25,76$ & $6 / 7,85.7$ & $4 / 7,57.2$ & $10 / 11,90.9$ & $13 / 16,81.3$ & $4 / 5,80$. & $2 / 5,50$ \\
\hline $\mathbf{1 4}$ & $14 / 25,56$ & $5 / 7,71.4$ & $2 / 7,28.6$ & $7 / 11,63.6$ & $7 / 15,46.6$ & $3 / 5,60$. & $4 / 5,80$ \\
\hline $\mathbf{2 1}$ & $23 / 25,92$ & $7 / 7,100$ & $6 / 7,85.7$ & $10 / 11,90.9$ & $13 / 14,92.9$ & $6 / 6,100$ & $4 / 5,80$ \\
\hline $\mathbf{2 8}$ & $14 / 25,56$ & $3 / 7,42.8$ & $3 / 7,42.9$ & $6 / 11,54.5$ & $8 / 14,57.1$ & $4 / 6,66.7$ & $2 / 5,40$. \\
\hline $\mathbf{4 3}$ & $25 / 25,100$ & $7 / 7,100$ & $7 / 7,100$ & $11 / 11,100$ & $13 / 13,100$ & $7 / 7,100$ & $5 / 5,100$ \\
\hline $\mathbf{5 8}$ & $12 / 25,48$ & $4 / 7,57.1$ & $2 / 7,28.6$ & $6 / 11,54.5$ & $5 / 11,45.5$ & $5 / 9,55.6$ & $3 / 5,60$. \\
\hline $\mathbf{7 3}$ & $8 / 25,32$ & $2 / 7,28.6$ & $3 / 7,42.9$ & $4 / 11,36.4$ & $3 / 8,37.6$ & $5 / 9,55.6$ & $7 / 7,100$ \\
\hline $\mathbf{8 8}$ & $24 / 25,96$ & $6 / 7,85.7$ & $7 / 7,100$ & $11 / 11,100$ & $7 / 8,87.5$ & $12 / 12,100$ & $5 / 7,71.4$ \\
\hline Total & $165 / 225$, & $47 / 63$, & $42 / 63$, & $76 / 99$, & $84 / 113$, & $51 / 64$, & $37 / 48$, \\
& 73.3 & $74.6 \%$ & $66.7 \%$ & $76.8 \%$ & $73.7 \%$ & 79.7 & $77.1 \%$ \\
\hline
\end{tabular}

P:Positive; T:Total, 


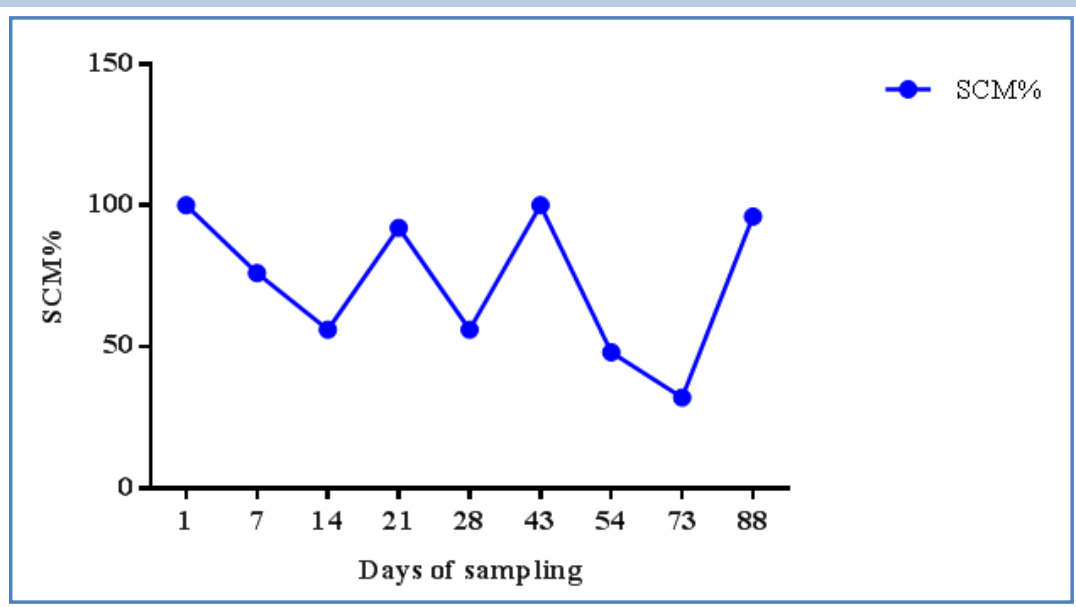

Figure 1 Prevalence of SCM based for period of $1^{\text {st }}$ to $88^{\text {th }}$ days.

For the purpose of studying the sequential prevalence of SCM, 25 cows were included in the study. The milk samples were collected from these cows at a weekly interval for five collections and followed by an interval of fifteen days collection for four times. The influence of factors such as the age, stage of lactation and milk yield were studied. A total of 225 milk samples were collected as detailed above.

\subsection{Somatic Cell Counting (SCC) using nucleocounter}

Fresh milk samples were used for SCC estimation using Nucleocounter (Chemo Metec, Denmark) following the instructions given by the manufacturer. Initially, five hundered microlitre of milk samples was mixed with equal quantity of the lysis buffer supplied by the manufacturer. The mixture was mixed gently to lyse the cells and was aspirated into the cassette by pressing the piston. The cassette was then inserted into the Nucleocounter and the SCC values were recorded. The SCC of > 5,00,000 cells / $\mathrm{ml}$ of test milk sample was considered cutoff to declare the positivity (Narayana \& Iya,1954).

\subsection{Multiplex polymerase chain reaction ( $\mathrm{mPCR}$ )}

Multiplex polymerase chain reaction was employed for the detection of bacterial pathogens in the milk samples. The specific primers sip, pau A, $16 S$ rRNA dys, alr and nuc were used to detect S. agalactiae, S. uberis, S. dysgalactiae, E. coli and S. aureus respectively (Hegde, 2011) .

\section{Results and Discussion}

In the present study, a total of 225 collections of milk samples from cows were tested by SCC. A preliminary evaluation of these samples revealed $73.33 \%$ prevalence of SCM. Sample ttest was performed on SCC with different days of sampling. No significant difference was observed between any collections in SCC $(\mathrm{P}>0.05)$. The prevalence of SCM was at various time points during the study period is shown in Table 1 and Figure.1.
The average SCC observed in SCM milk samples by earlier workers has exhibited variation and this could be because of primary / secondary pathogens of udder. These pathogens affected the mean SCC values depending on degree of infection (Samanta et al., 2006). Various other factors such as cytoplasmic environment, calving season and persistent contact / exposure to dung, high environmental humidity can also influence the incidence of SCM along with increased SCC in milk samples (Madsen et al., 1992).

The SCC in milk from individual cows generally is a useful tool for monitoring the probability of intramammary infection, but must be complemented with bacteriological identification and enumeration. Bacterial culture is routinely used to diagnose mastitis, and culture results are often the basis for evaluating the quality and extent of a problem at the herd level. However, bacterial culturing of milk samples is laborious and time consuming. Polymerase chain reaction based detection of various pathogens in the milk is a rapid, sensitive and reliable method of detecting mastitis causing pathogens (Khan et al., 1998; Phuektes et al., 2001a; Phuektes et al., 2001 b; Phuektes et al., 2003; Shome et al., 2011; Shome et al., 2012).

In the present study, a total of 225 milk samples were screened for major bacterial pathogens and 113 organisms were revealed by mPCR. Of these 113, Maximum S.aureus $(52.21 \%, 59 / 113)$ followed by S.dysgalactiae (15.93\%, 18/113), E.coli $(15.04 \%$, $17 / 113)$, S.agalactiae $(12.39 \%, 14 / 113)$ and S.uberis $(4.43 \%$, $5 / 113)$ were detected. This study was in accordance with Hedge et al., 2012 wherein $\mathrm{mPCR}$ results showed that S.aureus was a predominant pathogen detected $(53.77 \%)$ followed by S.dysgalactiae $(17.92 \%)$, E.coli $(13.12 \%), \quad$ S.agalactiae $(11.32 \%)$ and S.uberis (3.77\%) (Figure. 2).In this study, S.aureus was found to be the predominant pathogen prevailing at $52.21 \%$. Sequentially, the days when SCC and mPCR (S.aureus) were positive for SCM, the milk yield showed a negative trend as per Radostitis et al. (2000). 


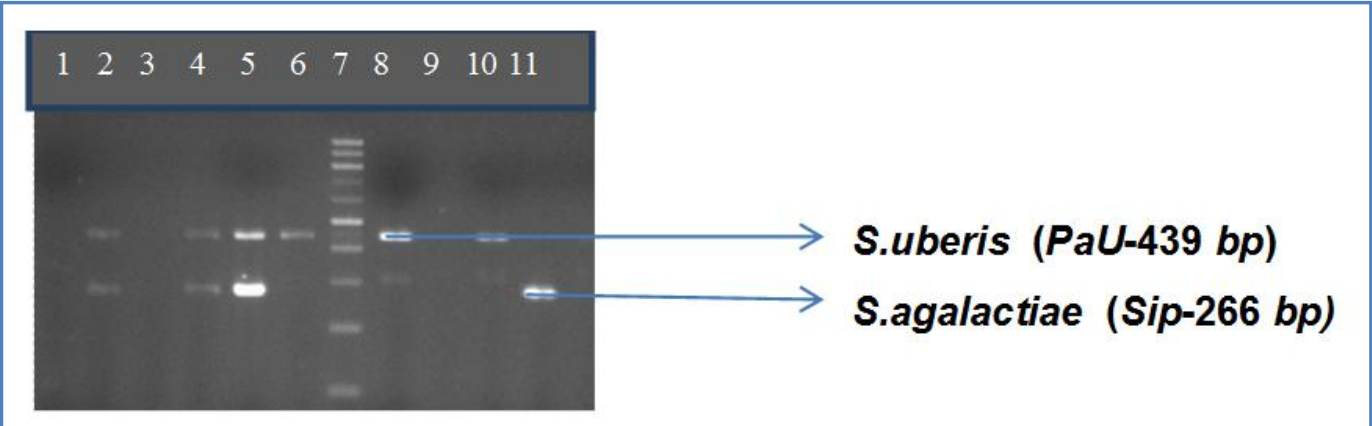

Figure 2 Two-tube Multiplex-Polymerase Chain Reaction (Tube 1) with milk samples for S.uberis (PaU-439 bp) and S.agalactiae (Sip266 bp ). [Lane Details : Lane 1,3,9: Negative for S.uberis and S.agalactiae; Lane 2,4,5: Positive for S.uberis and S.agalactiae; Lane 6,8,10: Positive for S.uberis; Lane 7: Ladder (100bp); Lane 11: Positive for S.agalactiae]

Only on certain days $(14,28,54$ and 73 days), there was not much influence on milk production though the organisms detected. As a predominant mastitis causing pathogen, S.aureus is able to survive for longer time on skin (McDonalds, 1977) and inside the neutrophils of the mammary gland (Craven \& Anderson, 1979; Sandholm et al., 1990) thus protecting itself from the action of antibiotics. This may be the reason that the SCC level remained elevated in our study on day $21^{\text {st }}$ and $43^{\text {rd }}$ due to intra cellular localization and in turn being protected from being acted upon by the antibiotics and acting as a immunogen. Boulanger et al.(2003) postulated that basal NF-kB activity is required for penetration of $S$. aureus into mammary epithelial cells, and that pharmacological NF-kB inhibitors could be used to reduce the intracellular infection of S. aureus (Hogan \& Smith, 2003).

Yet another predominant mastitis causing pathogen detected is Streptococci. With respect to the prevalence of environmental streptococcal mastitis, a large proportion of variability in its incidence and, both between geographical locations and within a single herd, can be ascribed to a number of independent variables such as season of the year, stage of lactation, parity, and various management practices (Hogan et al., 1989; Pankey et al., 1996; Hogan \& Smith, 2003). Streptococcus agalactiae is one of the obligate pathogen of mammary gland in case of bovines, colonizing the teat canal (Dodd, 1983). In our study, S.agalactiae was prevailing at $12.39 \%$.

The persistence of this organism is attributed to ill hygiene and general managemental factors. Further, $S$ dysgalactiae and $S$ uberis are other species associated with SCM. However, these species are not an obligate pathogen of mammary gland and they enter the udder by injurying the teat (Cullor \& Tyler, 1996). Furthermore, Sandholm et al. (1990) reported that S.dysgalactiae is a predominant pathogen associated with summer mastitis and it's frequent isolationfrom heifers and dry cows. While S.uberis being opportunistic could thrive and proliferate in tissues other than mammary glad. including lips, haircoat, tonsils and the rectum of cows (Bramley et al., 1979). Todhunter et al. (1994) opined that the rate of Streptococcal infection was high in summer season in lactating and dry cows. Further, the type of housing and associated managemental practices in the dairy farm could lead to the contamination of bedding materials and inturn expose teats to streptococci in the environment (Smith \& Hogan, 1993; Smith \& Hogan,1995). However, these factors do not appear to have contributed in the present study as the farm under investigation was well organized.

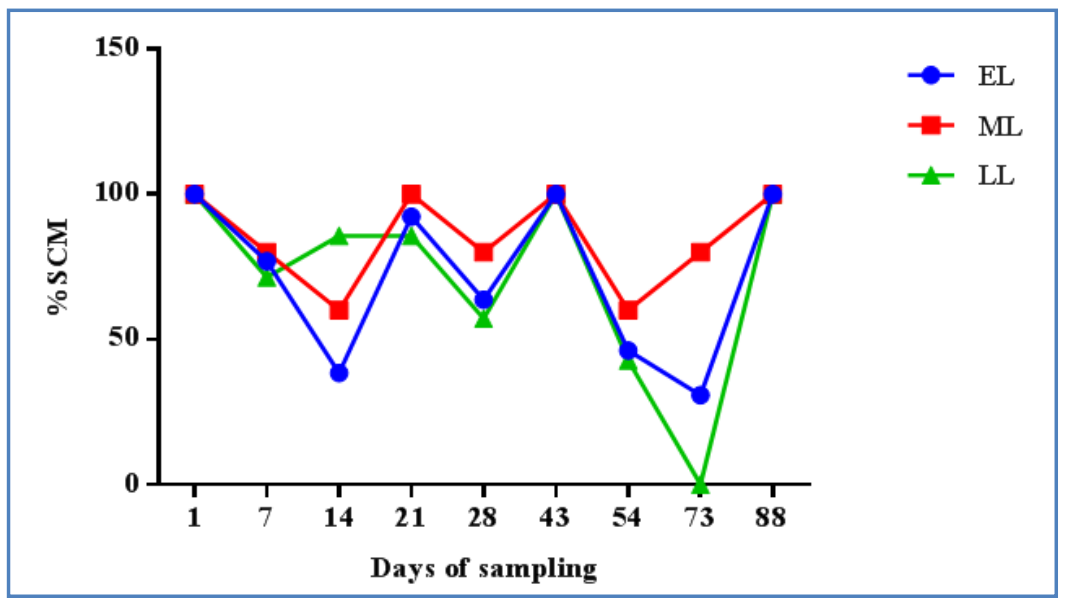

Figure 3a Prevalence of SCM based on SCC in different stage of lactation. 


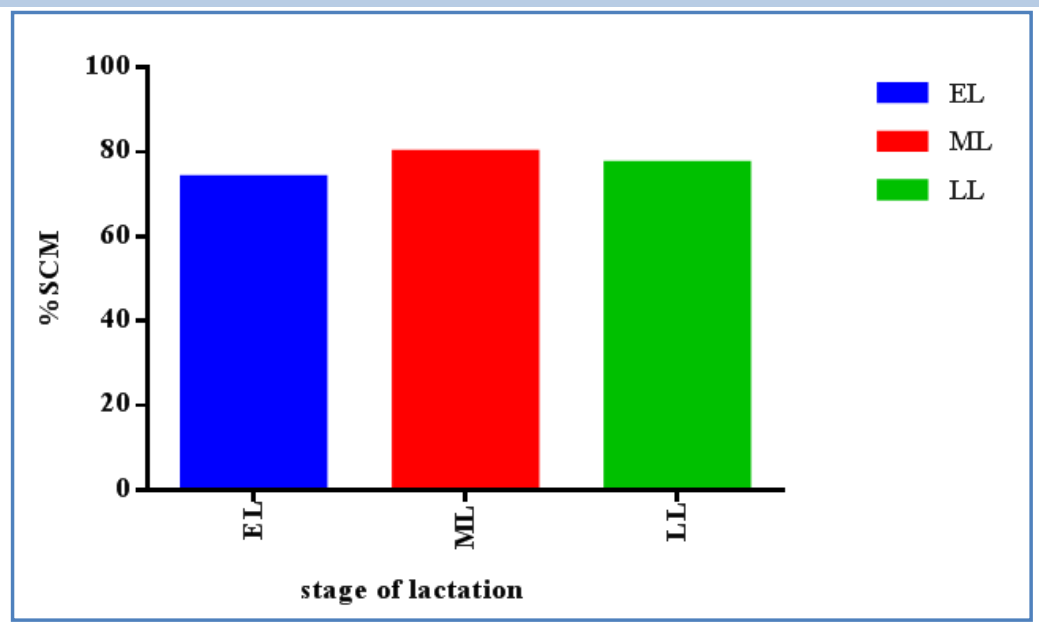

Figure $3 b$ Percentage prevalence of SCM based on SCC in different stage of lactation groups.

Escherichia coli is a Gram negative organism reported from the most of the bovine mastitis cases in both clinical mastitis (CM) and SCM. Although the infections due to E.coli are of short duration of <28 days (Todhunter et al., 1991), Many researchers reported the recurrent coliform mastitis and persistent infections due to E.coli in dairy animals. These studies concluded that the severity of mastitis due to E.coli is mainly related to host factors (Hill et al., 1979; Bradley \& Green, 2001). In present study, E.coli was found prevalent at $15.04 \%$, the days when SCC and MPCR were positive for SCM with the milk yield showing a negative trend. However, on certain days $\left(28^{\text {th }}, 54^{\text {th }}\right.$ and $\left.73^{\text {rd }}\right)$, there was no change in milk yield even in the presence of organism and this could be attributed to persistence stage / latent infection / carrier stage of infection / self cure, which is in agreement with Jayarao et al. (1999) who also reported that prevalence of IMI due to environmental pathogens might increase in the absence of contagious pathogens. Similarly, Schukken et al. (1989) also opined that low count of SCC due to decreased prevalence of contagious pathogens might lead to high prevalence of IMI due to environmental pathogens.

The appearance of mastitis pathogens in milk samples from a random sample of the cow population of this study revealed relationships between microbiological diagnosis and milk yield similar to those previously reported from clinical IMI. Multiplex PCR showed a similar variability as reported earlier (Hegde, 2011) and the benefits we experienced with mPCR were rapid, simple and accurate in revealing organisms. Viewed as a whole, study indicates that a positive diagnosis of $S$. aureus and Streptococcus species according to microbiological milk analysis of clinically normal cows correlates with production potential as opined by Reksen et al. (2007). In this study, M-PCR employed was a qualitative approach which detected the predominant species of bacteria involved in the SCM cases but not quantitative. It is necessary to estimate the bacterial load of different / various pathogens associated with SCM in order to understand the influence of the load of etiological agents on occurrence of SCM.
In the present study, the prevalence of SCM based on SCC during EL, ML and LL was $73.68 \%, 79.68 \%$ and $77.1 \%$ respectively (Figure.3a and 3b). The one-way ANOVA was performed on SCC of samples from the first collections to day 88 , at different stage of lactation. No significant differences was observed between any stage of lactation with respect to prevalence of SCM $(\mathrm{P}>0.05)$. In the present study, the prevalence of SCM based on SCC was high in the third lactation (75\%) which is in agreement with Islam et al. (2011) and Sripad et al. (2013) who have also reported high prevalence of SCM $(47.05 \%$ and $68.89 \%)$ during the third lactation. It is well established fact that bovine immune system is less capable of battling pathogens during the periparturient period. Although exact causes for a compromised immune system are not fully understood, they are believed to be at least influenced by hormonal and metabolic changes associated with pregnancy, parturition, and onset of lactation (Burvenich et al., 2003), Although exact causes for a compromised immune system are not fully understood, they are believed to be at least influenced by hormonal and metabolic changes associated with pregnancy, parturition, and onset of lactation (Burvenich et al., 2003), Additionally, during the peripartum period a substantial reduction in the levels of trace elements, protein and energy in blood that may result in occurrence of disease (Burvenich et al., 2003). Both CM and high milk production occur more commonly in older cows and in cows early in lactation (Bartlett et al., 1990).

The present study did not reveal any association between the stage of lactation and the prevalence of pathogens. The m PCR revealed the prevalence of predominant pathogens at $35.96 \%$ $(41 / 113)$ in EL; $29.68 \%$ (19/64) in ML and $33.33 \%$ (16/48) in LL Further, the application of m-PCR revealed $31.86 \%$ S.aureus (36/113), $1.77 \%$ S.agalactiae (02/113), $8.85 \% \quad S$. dysgalactiae (10/113), 0.89\% S.uberis (1/113), 8.85\% E.coli (9/113) in EL; $8.85 \%$ S.aureus (10/113), 6.2\% S.agalactiae (7/113), $1.77 \% \quad$ S.dysgalactiae (2/113), $1.77 \% \quad$ S.uberis (02/113), $1.77 \%$ E.coli $(2 / 113)$ in ML and $11.5 \%$ S.aureus (13/113), $1.77 \% \quad$ S.uberis $(02 / 113), \quad 4.43 \% \quad$ S.agalactiae 
(5/113), $4.43 \%$ S.dysgalactiae $(5 / 113)$ and $4.43 \%$ E.coli $(5 / 113)$ in LL. In all the stages of lactation, S.aureus was found predominant. Among three stages of lactation, maximum number of milk samples $(50 \%, 58 / 113)$ revealing the presence of pathogens were obtained from cows in the EL. However, this did not result in reduction in the milk yield during the EL. Based on this observation, it is evident that the varied distribution of organisms in different stages of lactation did not influence the prevalence of SCM and in turn affected the milk yield.

Singh \& Ludri (2001) opined that the milk yield varied significantly $(\mathrm{p}<0.01)$ during different stages of lactation and was also negatively correlated with SCC, whereas in our study there was low correlation between milk yield and SCC ( $\mathrm{r}=$ 0.038). Such weak correlation observed in the present work may be due to varied number of cows in different lactation stages. Furthermore, in our study, at different stages of lactation, the milk yield during the EL was at highest 3184.8 liters/cow (35.32\%), with milk loss of 242.2 liters/cow ( $2.82 \%)$, it was followed by ML with milk production at 2074 liters/cow (22.99\%) and milk loss of 792 litres / cow (8.78\%). Where as in LL, the milk production was 1609.3 litres / cow (17.85\%) with milk loss of 1113 litres / cow (12.34\%). The milk loss was highest in LL $(12.34 \%)$, followed by ML $(8.78 \%)$ and least loss in EL $(2.82 \%)$. The high milk yield in the EL than ML and LL in the present study is in accordance with the previous reports. Further, none of the tests employed indicated high prevalence of SCM in the EL as compared to ML and LL. Overall, the findings of the present study indicated that the stage of lactation did not influence on the prevalence of SCM.

In the present study, the animals were grouped into three age groups namely 3-5 years, 5-7 years and 7-11 years and the prevalence of SCM in these three age groups is $73.33 \%$, $66.66 \%$ and $76.76 \%$ respectively (Figure $4 \mathrm{a} \& 4 \mathrm{~b}$ ). Furthermore, the one-way ANOVA was performed on SCC with different age groups for sampling of all 9 collections.
Although, no significant difference was observed between the age groups with respect to SCC $(\mathrm{P}>0.05)$, and in turn the prevalence of SCM, relatively, the prevalence of SCM was higher in the age group 7-11 years. The SCC revealed the high prevalence of SCM $(76.76 \%)$ in 7-11 years as compared to 35 and 5-7 years age groups. The high prevalence of SCM with advancing age and in older cows draws support from the findings of earlier workers (Radostits et al., 2000; Qadri et al., 2005; Ul-Hah \& Malik, 2009).

Rahman et al. (2009) also reported that the prevalence of SCM significantly increased with age in dry as well as in wet season. Islam et al. (2011) reported that the prevalence of SCM was significantly higher in the age group of animals more than 13 years at 47.61 percent. The high prevalence of SCM in older cows could be attributed to suboptimal host defensive mechanisms (Dulin et al.,1988), prior exposure to the pathogens, cumulative SCM and carrier stage (Akbar et al., 2004). The higher prevalence of SCM in older animals than in younger cows could be attributed to suboptimal defense mechanism as indicated by Dulin et al. (1988). In addition, might be the other reason for the observation of as opined by Workineh et al. (2002). The higher prevalence of SCM in the aged cross bred cows as observed in the present study was also in accordance with Samanta et al. (2006) and Mustafa et al. (2007) .

The present findings are in agreement with the general observation that the mastitis incidence and SCC levels are both higher in older cows. This paradoxical finding could be well related to the functionality of the resident milk cells where in milk PMN in primiparous cows have been found to have a higher viability and ROS production as compared to older animals (Burvenich et al.,2003; Samanta et al., 2006). Further, the findings of the present study are also supported by the observation of Hogan \& Smith (2003) that the rate of IMI during the dry period was greater in multiparous cows compared with primiparous cows.

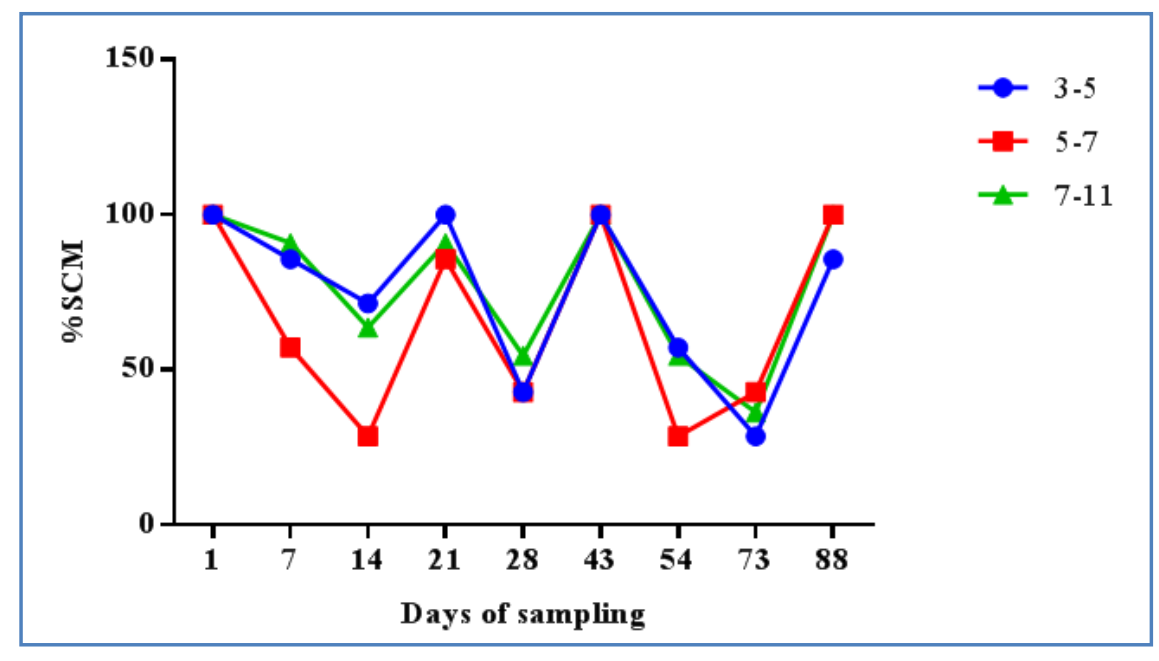

Figure 4a Prevalence of SCM based on SCC in different age groups. 


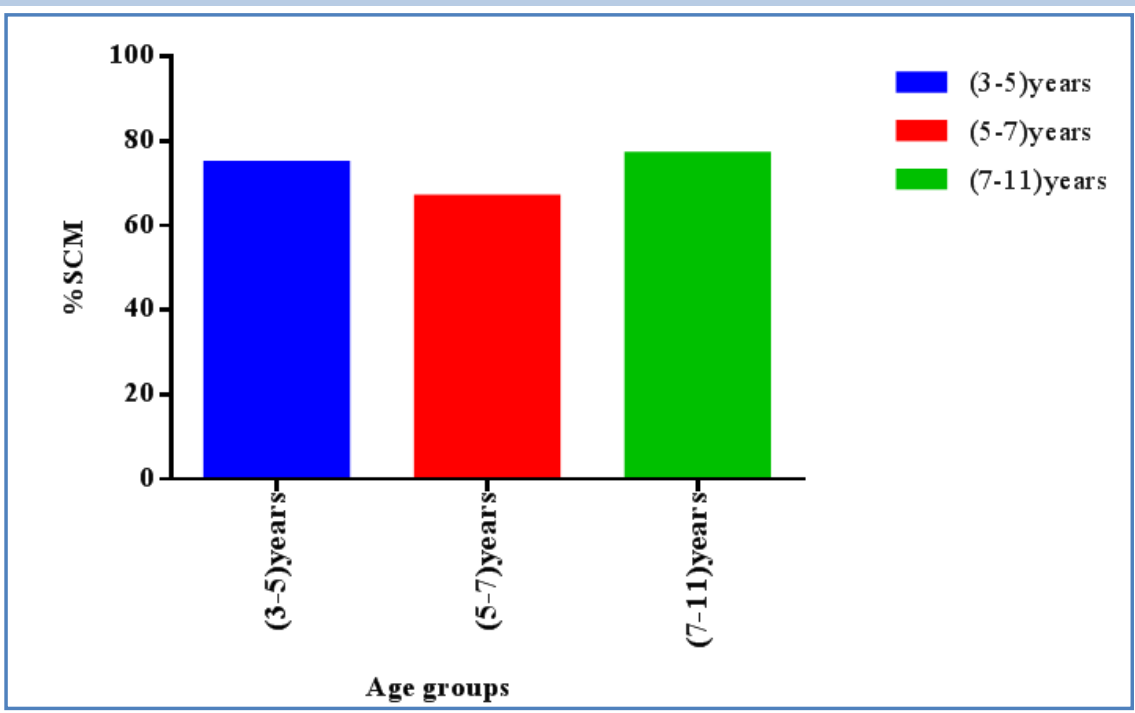

Figure $4 \mathrm{~b}$ Percentage prevalence of SCM based on SCC in different age groups.

High production cows appear to be at higher risk of developing CM. Also, both CM and high milk production occur more commonly in older cows Bartlett et al. (1990). Further, high prevalence of SCM in aged cows could also be attributed to the dilatation or partial opening of teat canal in case of older cows due to repeated milking. This encourages the introduction of environment and skin-associated microorganisms into the teat canal, leading to SCM and milk production losses. In addition, cows that are multiparous / aged have poor defence mechanism. Furthermore, elevated SCC due to minor pathogens could protect the mammary gland from major pathogens (Burvenich et al., 2003). Nevertheless, the correlation between SCC and the immune response of the udder to infection is complex and unclear.

With respect to the detection of major mastitis causing bacterial pathogens in different age groups of cows, the application of mPCR revealed the prevalence of S.aureus at $17.77 \%$ (20/113), S. dysgalactiae at $2.66 \%$ (3/113), E.coli at $4.43 \%(5 / 113)$, S.agalactiae at $1.77 \%(02 / 113)$, S.uberis at $1.77 \%(2 / 113)$ in age group of 3-5 years; S.aureus at $11.5 \%$ (13/113), S.agalactiae at $3.54 \%$ (4/113), S.dysgalactiae at $5.31 \%(6 / 113)$, E.coli at $4.43 \%(5 / 113)$ in age group of $5-7$ years and S.aureus at $23.0 \%$ (26/113), S.agalactiae at $7.1 \%$ (8/113), S.dysgalactiae at $7.1 \%(8 / 113)$, E.coli at $5.31 \%$ $(6 / 113)$ and S.uberis at $3.54 \%(4 / 113)$ in age group 7-11 years (Figure.4a and $4 \mathrm{~b}$ ). In all the age groups of cows, S.aureus was found predominant. Among three age groups, maximum number of milk samples $(46 \%, 52 / 113)$ revealing the presence of pathogens were obtained from cows in the age group 7-11 years. However, this did not affect the milk yield during the LL. In the study of Bartlett et al. (1990), pluriparous cows showed a milk loss of 2.06 times compared to that in the first lactation cows, milk loss of 1.40 times was observed in mastitic cows prior to 150 days in lactation compared to other cows and a milk loss of 1.37 times was seen in cows with mastitis during winter compared to summer season. However, in this study, the identity of the mastitis causing agent isolated from the clinical case was not strongly associated with the drop in milk production in the 60 day following clinical onset in Based on the observations of the present study and Bartlett et al. (1990), it is evident that the varied distribution of organisms in different age groups did not influence on the milk yield.

\section{Conclusion}

In conclusion, the present study revealed the high prevalence of variable SCM pattern in milking cows by SCC $(73.33 \%)$ using sequentially collected milk samples over a period of 88 days in an organized farm. No specific pattern of prevalence of SCM was observed in the sequentially collected milk samples during the study period. The prevalence of SCM was not influenced by the stage of lactation. In all the stages of lactation, S. aureus, Streptococci and E.coli were detected with the predominance of $S$. aureus. The varied distribution of organisms in different stages of lactation did not influence the prevalence of SCM. Further, the high prevalence of SCM was noticed in aged cows. The M-PCR revealed the presence of $S$. aureus, Streptococci and E.coli with the predominance of $S$. aureus in all the milk samples collected from all the three age groups. Among these groups, maximum number of milk samples $(46 \%, 52 / 113)$ revealing the presence of pathogens were obtained from cows in the age group 7-11 years. The MPCR assay employed in the present study was an easy and rapid method to detect the predominant pathogens causing SCM. Hence, the regular analysis of milk samples by M-PCR may be a useful tool for determining the herd status with regard to the detection of contagious and environmental mastitis pathogens. The result indicated the presence of both contagious and environmental mastitis pathogens. This emphasizes continuing need to concentrate on control both contagious pathogen such as $S$. aureus and environmental pathogen especially E.coli through sequential monitoring of 
SCM through application of SCC, M-PCR and proper managemental practices.

\section{Conflict of interest}

Authors would hereby like to declare that there is no conflict of interests that could possibly arise.

\section{References}

Akbar AN, Beverley PCL, Salmon M (2004) Will telomere erosion lead to a loss of T-cell memory ?. Nature Reviews Immunology 4: 737-743. DOI:10.1038/nri1440.

Bansal BK, Gupta DK (2009) Economic analysis of bovine mastitis in India and Punjab- A review. Indian Journal of Dairy Science $62: 337-345$.

Bartlett PC, Miller GY, Anderson CR, Kirk JH (1990) Milk production and somatic cell count in Michigan dairy herds. Journal of Dairy Science 73:2794. DOI:10.3168/jds.S00220302(90)78966-7.

Boulanger D, Bureau F, Melotte D, Mainil J, Ekeux P (2003) Increased nuclear factor $\mathrm{k}$ B activity in milk cells of mastitis affected cow. Journal of Dairy Science 86: 1259-1267. DOI: 10.3168/jds.S0022-0302(03)73710-2 .

Bradley AJ, Green MJ (2001) Adaptation of E.coli to the bovine mammary gland. Journal of Clinical Microbiology 39 : 1845-1849. DOI:10.1128/JCM.39.5.1845-1849.2001.

Bramley AJ, King JS, Higgs T M (1979) The isolation of Streptococcus uberis from cows in two dairy herds. British Veterinary Journal 135:262-270.

Brand A, Noordhuizer JPM, Schukkem YH (1996) Veterinary herd health and production management in dairy practice. Wageningen Pres Publication Wageningen, The Netherlands

Burvenich C, Merris VV, Merszad J, Araceli DF, Uchateau L (2003) Severity of E.coli mastitis is mainly determined by cow factors. Veterinary Research 34:521-564. DOI: 10.1051/vetres:2003023.

Craven N, Anderson J C (1979) The location of Staphylococcus aureus in experimental chronic mastitis in the mouse and the effect on the action of sodium cloxacillin. British Journal of Experimental Pathology 60:453-459.

Cullor JS, Tyler JW (1996) Mammary Gland Health and Disorder. In: Smith Bradford P (Ed.) Large Animal Internal Medicine 2nd Ed., Mosby, St. Louis, pp. 1178-1193.

Dodd FH (1983) Mastitis-Progress on Control. Journal of Dairy Science 66:1773-1780.
Dulin AM, Paape MJ, Nickerson SC (1988) Comparison of Phagocytosis and chemiluminescence by blood and mammary gland neutrophils from multiparous and nulliparous cows. American Journal of Veterinary Research 49: 172- 177.

Harmon RJ (1994) Physiology of mastitis and factors affecting somatic cell counts. Journal of Dairy Science 77:2103-2112. DOI: http://dx.doi.org/10.3168/jds.S00220302(94)77153-8.

Halasa T, Huijps K, Osteras O, Hogeveen H (2007) Economic effects of Bovine mastitis and mastitis management: A review. Veterinary Quarterly 29: 18-31. DOI:10.1080/01652176.2007.9695224

Hegde R (2011) Rapid identification of bacterial pathogens causing subclinical bovine mastitis with special reference to Staphylococcus aureus, Escherichia coli and predominant streptococcal species by molecular methods. $\mathrm{PhD}$ Thesis submitted to the Karnataka Veterinary, Animal and Fisheries Sciences University, Bidar.

Hill AW, Shears AL, Hibbit KG (1979) The survival of serum resistant E.coli in the bovine mammary gland following experimental inflammation. Research in Veterinary Science 26: $32-37$.

Hogan JS, Smith KL, Hoble KH, Schoenberger PS, Todhunter WD, Hueston WD, Pritchard E, Bowman GL, Heider LE, Brockett, BL, Conrad HR (1989) Field survey of mastitis in low somatic cell count herds. Journal of Dairy Science 72:1547-1556.

Hogan JS, Smith KL (2003) Environmental Streptococcal Mastitis: Facts, Fables, and Fallacies. National Mastitis Council Annual Meeting Proceedings Ohio Agricultural Research and Development Center. The Ohio State University Wooster, Ohi, pp. 162-172.

Islam MA, Rahman MS, Islam MA, Islam MT (2011) Prevalence of Sub-clinical Mastitis in dairy cows in selected areas of Bangladesh. Bangladesh Journal of Veterinary Medicine 9 :7378.DOI:http://dx.doi.org/10.3329/bjvm.v9i1.11216.

Jayarao BM, Gillespie BE, Lewis MJ, Dowlen HH, Oliver SP (1999) Epidemiology of Streptococcus uberis Intramammary Infections in a Dairy Herd. Journal of Veterinary Medicine Series B 46:7,433-442.

Khan M A, Kim CH., Kakoma I, Morin E, Hansen RD, Hurley WL, Tripathy DN, Baek BK (1998) Detection of Staphylococcus aureus in milk by use of polymerase chain reaction analysis. American Journal of Veterinary Research 59: 807-813. 
Madsen M, Sorensen GH, Aalbaek B, Hansen JW, Bjorn H (1992) Summer mastitis in heifers: Studies on the season occurrence of Actinomyces pyogenes, Petostreptococcus indolicus and Bacteriodaceae in clinically healthy cattle in Denmark. Veterinary Microbiology 30: 234-255.

Mcdonalds JS (1977) Streptococcal and Staphylococcal Mastitis. Journal of the American Veterinary Medical Association 170 : 1157-1159.

Mustafa MY, Hassan SS, Ahmad MD (2007) Frequency of occurrences of mastitis in different quarters of udder and its cure-a field study. Biologia 53:51-57.

Narayana T, Iya KK (1954) Studies on bovine mastitis .Incidence of mastitis in cows and buffaloes. Indian Journal of Dairy Science 6: 15-25.

Nithinprabhu K, Isloor $\mathrm{S}$, Hegde R, Rathnamma D, Veeregowda BM, Murthy HNN, Shome R, Suryanarayana VVS (2013) Development of polymerase chain reaction for detection of predominant streptococcal isolates causing subclinical bovine mastitis. Indian Journal of Biotechnology 12: $208-212$.

Pankey JW, Pankey PB, Barker PM, Williamson JH, Woolford MW (1996) The prevalence of mastitis in primiparous heifers in eleven Waikato dairy herds. New Zealand Veterinary Journal 44:41-44.

Phuektes P, Browning G, Anderson G, Mansell P (2003) Multiplex polymerase chain reactionas a mastitis screening test for Staphylococcus aureus, Streptococcus agalactiae ,Streptococcus dysgalactiae and streptococcus uberis in bulk milk samples. Journal of Dairy Research 70 :149-55.

Phuektes P, Browning GF, Anderson G, Mansell PD (2001a)Polymerase chain reaction based study on the subclinical mastitis caused by Streptococcus agalactiae, S.dysgalactiae and S.uberis in cattle in Ahvaz. Iranian Journal of Veterinary Research 8:260-265.

Phuektes P, Mansell PD, Browning GF, (2001b) Multiplex polymerase chain reaction assay for simultaneously detection of Staphylococcus aureus and treptococcal causes of bovine mastitis. American Dairy Sciences Association .84:1140-1148. DOI:10.3168/jds.S0022-0302(01)74574-2.

Qadri F, Svennerholm Ann-Mari, Faruque ASG, Sack R (2005) Enterotoxigenic Escherichia coli in developing countries: epidemiology, microbiology, clinical features, treatment and prevention. Clinical Microbiology Reviews 18:465-483. DOI: 10.1128/CMR.18.3.465-483.2005.

Radostitis OM, Gay CC, Blood DC, Hinchcliff KW Eds. (2000) Mastitis. In: Veterinary Medicine, A Text book of the diseases of Cattle, Sheep, Pigs, Goat, and Horse, 9thEdn, W B Saunders Company, Philadephia .
Rahman MA, Bhuiyan MMU, Kamal MM, Shamsuddin M (2009)Prevalence and risk factors of mastitis in dairy cows. The Bangladesh Veterinarian 26: 54-60. DOI: 10.3329/bvet.v26i2.4951.

Reksen O, Sølverød L, Østeras O (2007) Relationships between milkculture results and milk yield in Norwegian dairy cattle. Journal of Dairy Science 90:4670-4678. DOI:10.3168/jds.2006-900

Samanta A, Prasad S, Ghosh CP (2006) Incidence of SCM IN Karan-Swiss and Karan-Fries cross bred cows. Indian Journal of Dairy Science $59: 13-18$.

Sandholm M, Kaartinin L, Pyorala S (1990 Bovine mastitis why does antibiotic therapy not always work ? An overview. Journal of Veterinary Pharmacology and Therapeutics 13: 24860.

Schukken YH, Grommers FJ, Geer Dvan DE, Brand A (1989) Incidence of clinical mastitis on farms with low somatic cell counts in bulk milk. Veterinary Record 125 : 60-63.

Shome BR, Mitra DS, Bhuvana M, Krithiga N, Shome R, Velu D, Prabhudas K (2012) Multiplex PCR for thedetection of five important Staphylococcus species in bovine subclinical mastitis milk. The Indian Journal of Animal Sciences 82 : 914.

Shome BR, Mitra AS, Bhuwana M, Krithiga N, Velu D, Shome R, Isloor S, Barbuddhe SB, Rahman H (2011) Multiplex PCR assay for species identification of bovine mastitis pathogens. Journal of Applied Microbiology: 13645072. DOI:10.1111/j.1365-2672.2011.05169.x

Singh M, Ludri RS (2001) Influence of stages of lactation, parity and seasons on somatic cell count in cows. AsiansAustralian Journal of Animal Science 14 :1775-1780.

Smith KL, Hogan JS (1993) Environmental mastitis. Veterinary Clinics of North America: Food Animal Practice 9:489-498.

Smith KL, Hogan JS (1995) Epidemiology of mastitis. Proceedings of Third International Dairy Federation and International Mastitis Seminar, Book II, Session 6. Tel-Aviv, IL: 3-12.

Sripad K, Upendra HA, Isloor S, Yathiraj S (2013)Prevalence of Subclinical Mastitis in Organised Farm in and around Banglore. Frontier Journal of Veterinary and Animal Science 2: 109-112.

Todhunter DA, Smith KL, Hogan JS, Choenberger PS (1991) Gram-negative bacterial infections of the mammary gland in cows. American Journal of Veterinary Research 52:184-188. 
Todhunter DA, Smith KL, Hogan, J S (1994) Environmental Streptococcal Mastitis .Special Circular Ohio Agricultural Research Development Centre (OARDC) Dairy Science Research Highlights pp 41-43.

Workineh S, Ayleyegn M, Mekonnenh, Potgieter LND (2002) Prevalence and aetiology of mastitis in cows from two major
Ethiopian dairies. Tropical Animal Health Production 34: 1925. doi:10.1023/A:1013729626377.

Ul-Haq Z, Malik, HU (2009) Prevalence of bovine mastatisunder different husbandry conditions of Kashmir. Applied Biological Research 11: 36-39. 